\title{
Production of Bacillus thuringiensis Berliner var. kurstaki Grown in Alternative Media
}

\author{
L. F. A. ALVES, ${ }^{1}$ S. B. ALVES, ${ }^{1}$ R. M. PEREIRA ${ }^{2}$ AND D. M. F. \\ CAPALBO ${ }^{3}$ \\ ${ }^{1}$ Departamento de Entomologia, ESALQ-USP, Caixa Postal 9, 13418-900 \\ Piracicaba, SP, Brazil; ${ }^{2}$ Department of Entomology \& Nematology, University \\ of Florida, PO Box 110620, Gainesville, FL 32611-0620, USA; \\ ${ }^{3}$ EMBRAPA-CNPMA, Caixa Postal 69, 13820-000 Jaguariúna, SP, Brazil
}

(Received for publication 17 September 1996; revised manuscript accepted 13 April 1997)

\begin{abstract}
Agro-industrial residues and by-products available in southeastern Brazil were used as ingredients for low-cost culture media for liquid fermentation of Bacillus thuringiensis var. kurstaki. Highest spore yield was obtained with a medium containing cheese whey, soya bean milk and molasses (WSM). Crystals and spores were produced in all media and potency of the final product was highest for nutrient broth + yeast extract medium (NBY). There was no correlation between the number of spores in the fermented media and the potency of the preparations. Considering all three factors, the potencies, costs and yields of the final products, lowest relative cost was obtained with BMM medium (Bombyx mori pupae + molasses). NBY and WSM had intermediate relative cost approximately nine times higher than BMM. The cost analysis suggests that BMM medium should be preferred for local production of $\mathrm{B}$. thuringiensis var. kurstaki in comparison to other media tested. The results also demonstrate the importance of considering yields, cost and potency of the $\mathrm{B}$. thuringiensis preparations in selecting the production medium.
\end{abstract}

Keywords: Bacillus thuringiensis, media, production, entomopathogenic bacterium, microbial control, biological control

\section{INTRODUCTION}

Entomopathogenic bacteria are promising agents for biological control of pests and disease vectors. Usually, they are easily produced in vitro by liquid fermentation. Culture media, an important part of the production cost of these organisms, can contain ingredients which are costly and difficult to obtain in developing countries. In these countries, research on the development and improvement of culture media can have a significant effect on widening the spectrum of use of these agents, by lowering production costs and increasing yields. An important aspect of cutting costs can be the substitution of high-cost medium ingredients

Correspondence to: R. M. Pereira, Department of Entomology \& Plant Pathology, 205 Ellington Plant Science Building. University of Tennessee, PO Box 1071, Knoxville, TN 37901-1071, USA. 
by complex regional agro-industrial residues and by-products. These ingredients can have low cost and high availability (Briggs, 1963; Salama et ${ }^{\circ}$ al., 1983a; Capalbo et al., 1991).

Recently, Foda et al. (1993) and Pantuwatana et al. (1993) recommended that developing countries produce bacteria for microbial control locally, using available residues and by-products. Besides lower cost, better quality assurance can be accomplished by avoiding long-distance transportation of the biological pesticides between the production site and the final users.

Agro-industrial residues and by-products used in Bacillus thuringiensis production include: molasses, starch, casein, cotton and soya bean seed meals, fodder yeast, corn steep liquor, cheese whey, dried residues from chicken slaughterhouses and coconut water (Scherrer et al., 1973; Fernandez et al., 1975; Couch \& Ross, 1980; Salama et al., 1983a,b,c; Arcas et al., 1984; Alves et al., 1993; Ventosilla et al., 1994). In general, the results of these studies show that media with these ingredients can produce high yields of spores and crystals with high entomopathogenic activity.

Reported here is the testing of agro-industrial residues and by-products available in southeastern Brazil as components for low-cost culture media used for liquid fermentation of $B$. thuringiensis var. kurstaki.

\section{MATERIALS AND METHODS}

B. thuringiensis var. kurstaki serotype $\mathrm{H}$ : $3 \mathrm{a}-3 \mathrm{~b}$ was obtained from the commercial product Dipel PM (Abbott Lab., Chicago, IL, USA) and cultured on nutrient agar (NA) medium (Difco Labs Ltd, Surrey, UK). Stock cultures were stored on slants under sterile mineral oil at $4-10^{\circ} \mathrm{C}$. For each production batch, inoculum was removed from the stock cultures with a sterile loop and transferred to NA plates. These plates were incubated for $24 \mathrm{~h}$ at $30^{\circ} \mathrm{C}$ and a loopful of these bacterial colonies was transferred to $50 \mathrm{ml}$ of nutrient broth (Difco Labs Ltd) in 250-ml Erlenmeyer flasks. The liquid medium was then incubated for $24 \mathrm{~h}$ at $30 \pm 1{ }^{\circ} \mathrm{C}$ on a gyratory shaker at $120 \mathrm{rpm}$ (pre-fermentation). Aliquots $(1 \mathrm{ml})$ were removed from the pre-fermentation flasks and transferred to flasks containing $50 \mathrm{ml}$ of the media to be tested.

For the initial medium selection, 43 combinations of ingredients were tested including: fodder yeast, soya bean milk and protein from leguminous seeds (Phaseolus vulgaris and Glycine max), cheese whey, sugar cane molasses, ground Bombyx mori pupae, glycerol, sucrose, industrial residue of the production of monosodium glutamate, and salts $\left(\mathrm{CaCO}_{3}\right.$ and $\mathrm{MnSO}_{4}, \mathrm{H}_{2} \mathrm{O}$ ). Methods and results are described in Alves et al. (1997).

Based on results described in Alves et al. (1997), three media (Table 1) were selected for further testing. These three media were selected for their high spore yields and availability of ingredients in Brazil (Alves et al., 1997). Nutrient broth $+0.1 \%$ yeast extract (NBY; Difco Labs Ltd) was used as the standard for comparison. For each medium, 36 flasks were prepared and incubated as described previously. Every $4 \mathrm{~h}$ until completion of the fermentation process after $48 \mathrm{~h}$, samples were taken from four randomly chosen flasks for each medium, and $\mathrm{pH}$ and spore counts were determined.

To determine spore counts, samples $(2 \mathrm{ml})$ were heated in a water-bath at $80^{\circ} \mathrm{C}$ for $10 \mathrm{~min}$ and then chilled on ice for $5 \mathrm{~min}$. This heat/cold shock lyzed the vegetative cells and liberated those spores already formed in the bacterial cells, facilitating microscope observation. After serial dilution with distilled water + weeting/dispersion agent (Tween 80 at $0.01 \%$ ), the number of spores were counted in Petroff-Hauser cell-counting slides, using a phase-contrast microscope. Spores were identified by their shape and phase bright appearance under the microscope. Spore counts were used as an easily obtained estimate of the concentration of the spore-toxic crystal complex. Later results were adjusted according to the potency of the fermentation products, which reflects the actual amount of the toxic protein in the preparations. 
The potencies of the fermentation products were tested against third-instar Anticarsia gemmatalis grown on artificial diet (Greene et al., 1976, minus formaldehyde). The fermentation products were centrifuged $(15 \mathrm{~min}$ at $6000 \mathrm{rpm})$ and resuspended in distilled water several times to eliminate culture medium. Final products were diluted to obtain concentrations of $10^{1}, 10^{3}, 10^{5}, 10^{7}$ and $10^{9}$ spores $/ \mathrm{ml}$, and $50 \mu \mathrm{l}$ of these suspensions were added to the surface of artificial diet in glass tubes $(2.5 \mathrm{~cm}$ diameter $\times 8.0 \mathrm{~cm}$ height $)$. Larvae were added individually to diet tubes after spore suspensions had soaked into the diet. One hundred larvae, divided into four replicates, were used for each treatment and maintained at $26^{\circ} \mathrm{C}, 60 \%$ relative humidity (RH) and 14-h photophase. Mortality of larvae and the identity at the causal agent (as determined by microscope observation of insect cadavers) were recorded daily until larval development was completed. Mortality data were analyzed using a Logit transformation, and lethal concentrations for $50 \%$ of the tested populations $\left(\mathrm{LC}_{50}\right)$ were obtained for each medium. Spore yield and $\mathrm{LC}_{50}$ values were used to calculate volumes $(\mathrm{ml})$ of the fermented media needed to prepare 11 of suspension at $\mathrm{LC}_{50}$ (volume in $\mathrm{ml}=\mathrm{LC}_{50} \times 10^{3} /$ yield). This allowed the comparison of the cost for all media using a common parameter, and the calculation of a relative cost for each medium used. Dilution factors were calculated as $\log _{10}$ of dilutions necessary to bring fermented broths down to $\mathrm{LC}_{50}$.

Medium samples were also analyzed for their protein and sugar compositions by methods described by AOAC (1975) and Tosi and Favoretto (1989). The costs of the culture media were determined based on the ingredient prices in the southeastern region of Brazil. The media were compared based on their cost, spore yield and potency against A. gemmatalis larvae. These data were used in calculating the relative cost for all media used, as the cost of 10001 of suspension at $\mathbf{L C}_{50}$ (relative cost $=$ medium cost/ $10^{\text {(dilution factor) }}$. This new variable takes into consideration the costs and yields of the different media but adjusts for the differences in potencies observed for the final fermentation products when tested against the soya bean caterpillar.

\section{RESULTS AND DISCUSSION}

The nutritional composition of the media used in the experiments are presented in Table 1. Except for the standard medium, NBY, all other media contained $0.5 \%$ of sugar cane molasses. NBY was the medium with the highest concentration of protein in relation to carbohydrate, with a carbon:nitrogen $(\mathrm{C}: \mathrm{N})$ ratio of $1: 26$. The medium with the highest concentration of carbohydrates was that with milk whey and soya bean milk (WSM), with

TABLE 1. Nutritional composition of the media selected in the first phase experiments

\begin{tabular}{lcccc}
\hline \multirow{2}{*}{$\begin{array}{l}\text { Media } \\
\text { composition }\end{array}$} & & \multicolumn{2}{c}{ Composition (\%) } & \\
\cline { 3 - 4 } & Acronym & Soluble carbohydrates & Protein & C:N ratio \\
\hline $\begin{array}{c}\text { Nutrient broth }+ \\
\text { yeast extract } 0.1 \%\end{array}$ & NBY & 3.21 & 82.69 & $1: 26$ \\
$\begin{array}{c}\text { Cheese whey } 50 \%+ \\
\text { soya bean milk 10\% }\end{array}$ & WSM & 24.14 & 35.46 & $1: 1.5$ \\
$\begin{array}{c}\text { Soya bean protein } \\
\text { Soy }\end{array}$ & SPM & 26.93 & 46.26 & $1: 1.7$ \\
$\begin{array}{c}\text { Ground Bombyx mori } \\
\text { pupae } 15 \%\end{array}$ & BMM & 15.76 & 46.14 & $1: 2.9$ \\
\hline
\end{tabular}

${ }^{a}$ WSM, SPM and BMM also contained $0.5 \%$ sugar cane molasses.

${ }^{b}$ Carbohydrates/Protein.

'Nutrient broth from Difco Labs Ltd. Soybean protein was Samprosoy 90 (Sanbra SA, São Paulo, Brazil). 


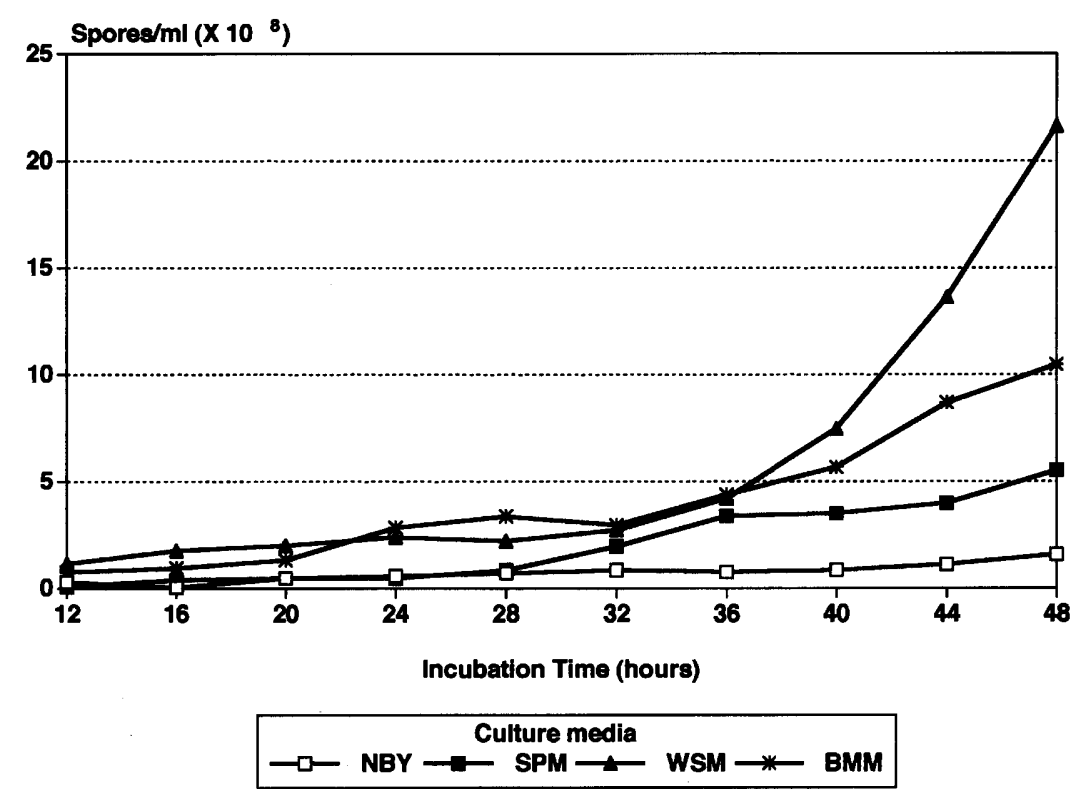

FIGURE 1. B. thuringiensis var. kurstaki spore yields in different liquid media. (See Table 1 for medium compositions.)

1:1.5 C:N ratio. The medium containing ground Bombyx mori pupae (BMM) had C:N ratio equal to $1: 1.7$, and the medium containing soya bean protein (SPM) had $C: N$ ratio equal to $1: 2.9$.

Highest spore yield was obtained in WSM medium with $21.6 \times 10^{8}$ spores $/ \mathrm{ml}$ after incubation for $48 \mathrm{~h}$ (Figure 1). This result is twice the yield achieved in BMM, which produced $10.5 \times 10^{8}$ spores $/ \mathrm{ml}$, and four times the yield in SPM $\left(5.5 \times 10^{8}\right.$ spores $\left./ \mathrm{ml}\right)$. The standard medium was very poor for production of $B$. thuringiensis spores, with only $7.3 \%$ of the yield obtained with WSM. Spore production for WSM medium increased sharply after $40 \mathrm{~h}$, and was significantly larger than all other media after this time. Significant differences were also observed between all other media at $40 \mathrm{~h}$ and thereafter.

The use of soya bean products in culture media has been associated with high spore yields for B. thuringiensis by other authors (Goldberg et al., 1980; Mummigatti \& Raghunathan, 1990). The combination of cheese whey and soya bean was also studied by Salama et al. (1983a) who obtained maximum yields of $2 \times 10^{8}$ spores $/ \mathrm{ml}$. The maximum yields presented herein are 2 to 10 times higher than those cited by those authors. Yields obtained with WSM medium are comparable to those obtained by Goldberg et al. (1980) in 500-1 fermenters containing medium with glucose, peptone and mineral salts. However, yields obtained with WSM are approximately 10 times lower than those obtained by Rodriguez et al. $(1993)\left(2.7 \times 10^{10}\right.$ spores $\left./ \mathrm{ml}\right)$. Lower yields in high-protein media may be due to the production and accumulation of nitrogen metabolites. According to Pearson and Ward (1988), these metabolites regulate, through a feedback mechanism, the production of spores and crystals during fermentation of $B$. thuringiensis.

The pH curves for all media (Figure 2) had a typical pattern (Pearson \& Ward, 1988; Sakharova et al., 1988; Capalbo et al., 1991), with decline in $\mathrm{pH}$ during the log phase of fermentation (initial phase), followed by increase to $\mathrm{pH}$ levels close to or higher than the initial $\mathrm{pH}$. NBY showed little decline in $\mathrm{pH}$ during the first $4 \mathrm{~h}$, and rapid increase for the next $12 \mathrm{~h}$, reaching a final $\mathrm{pH}$ just above 9. The $\mathrm{pH}$ curves for WSM and BMM were very similar with rapid initial decline and slow increase afterward. For SPM, the increase in $\mathrm{pH}$ after the initial decline was faster than for WSM and BMM, but the $\mathrm{pH}$ values for all 

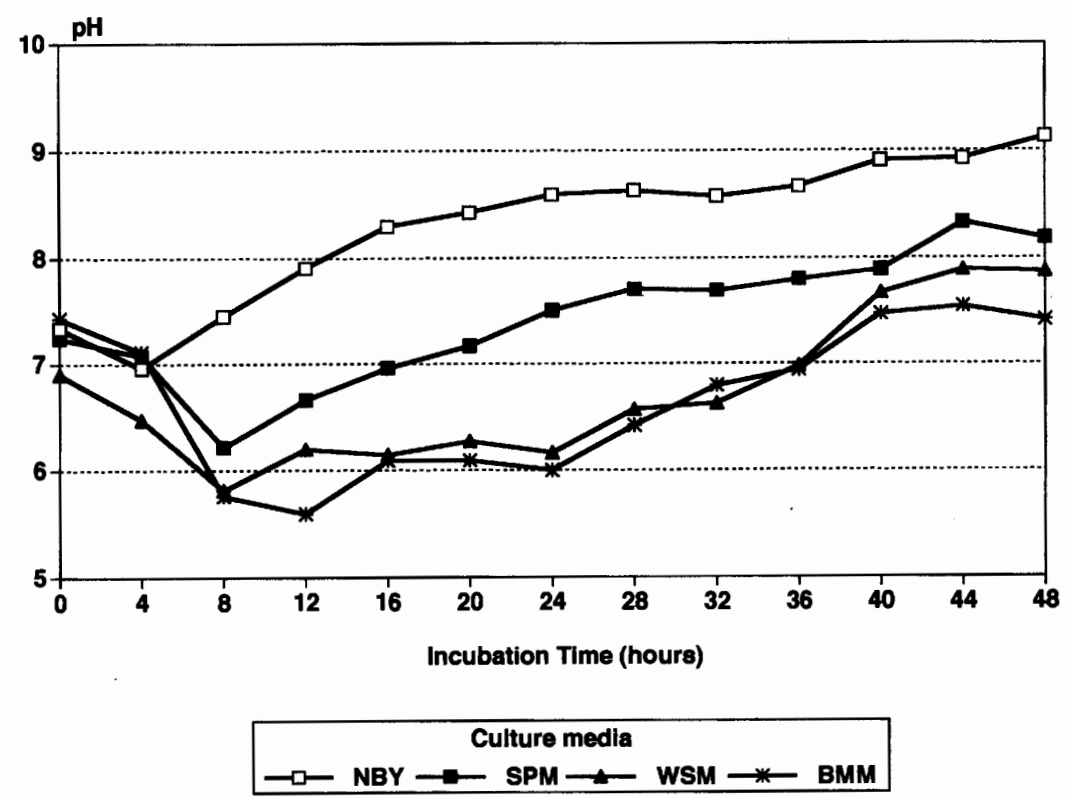

FIGURE 2. Medium pH during $B$. thuringiensis var. kurstaki fermentation in different liquid media. (See Table 1 for medium compositions.)

media except the standard were very similar after $48 \mathrm{~h}$. High $\mathrm{pH}$ is optimal for $B$. thuringiensis proteases and potentially damaging to the crystals, therefore fermentation liquid should be brought to neutral $\mathrm{pH}$ at harvest.

Crystals and spores were produced in all media, but potency of the final products varied and could not be predicted from the number of spores produced. Highest potency was obtained with NBY medium which had an $\mathrm{LC}_{50}$ of $3.0 \times 10^{6} \mathrm{spores} / \mathrm{ml}$, corresponding to $18.9 \mathrm{ml}$ of the fermented medium to produce 11 of suspension at $\mathrm{LC}_{50}$ (Table 2). In contrast, $\mathrm{LC}_{50}$ 's for WSM, SPM and BMM were $2.5 \times 10^{8}, 1.7 \times 10^{7}$ and $2.3 \times 10^{8}$ spores $/ \mathrm{ml}$, corresponding to 117,309 and $216 \mathrm{ml}$ of the fermented media respectively.

There was no correlation between the number of spores in the fermented media and the potency of the preparations. For example, the use of ground B. mori pupae (BMM medium) allowed high production of spores but decreased the potency of the final product. These results suggest that the production of spores is not well correlated with the biological activity. Rich media, such as NBY, may have allowed the germination of spores and a consequent accumulation of higher concentrations of crystal protein in a medium with relatively low numbers of spores. Dulmage (1970) also observed that the composition of the media affected the yields and toxin production for several varieties of $B$. thuringiensis. The size, shape and toxin content of crystals can be affected by the concentration of carbohydrates in the medium (Scherrer et al., 1973). Faloci et al. (1993) also observed that medium composition affected the $\delta$-endotoxin concentration in the crystal and toxic activity of B. thuringiensis. In the present study, the medium effects on crystal shape and composition were not evaluated, but these effects may explain the different potencies observed for the fermentation products.

The cost per liter of medium varied widely from US\$1.76 for NBY to approximately US $\$ 0.02$ for BMM (Table 2). The costs associated with medium ingredients, the potencies $\left(\mathrm{LC}_{50}\right)$ and yields of final products were considered during the calculation of the final relative cost. Lowest relative cost was obtained with BMM medium (US\$4.31), whereas SPM had the highest relative cost (US\$68.00). NBY and WSM had intermediate relative costs of US\$33.31 and US\$51.33 per 10001 of suspension at $\mathrm{LC}_{50}$ respectively. Although 
TABLE 2. Spore yields, $\mathrm{LC}_{50}$ and relative cost for production of $B$. thuringiensis var. kurstaki in different liquid media

\begin{tabular}{|c|c|c|c|c|c|c|}
\hline \multirow[b]{2}{*}{$\operatorname{Media}^{a}$} & \multirow{2}{*}{$\begin{array}{c}\text { Yield } \\
\left(\times 10^{8} \text { spores } / \mathrm{ml}\right)\end{array}$} & \multicolumn{2}{|c|}{$\mathrm{LC}_{50}$} & \multirow[b]{2}{*}{ Dilution factor ${ }^{d}$} & \multirow{2}{*}{$\begin{array}{l}\text { Cost } / /^{e} \\
\text { (US\$/l) }\end{array}$} & \multirow{2}{*}{$\begin{array}{l}\text { Relative cost }{ }^{f} \\
\text { (US\$) }\end{array}$} \\
\hline & & $(\text { spores } / \mathrm{ml})^{b}$ & Volume $(\mathrm{ml})^{c}$ & & & \\
\hline NBY & 1.58 & $\begin{array}{c}2.99 \times 10^{6} \\
\left(0.92-8.16 \times 10^{6}\right)\end{array}$ & 18.9 & 1.72 & 1.76 & 33.31 \\
\hline WSM & 21.6 & $\begin{array}{c}2.52 \times 10^{8} \\
\left(0.52-7.00 \times 10^{8}\right)\end{array}$ & 116.7 & 0.93 & 0.44 & 51.33 \\
\hline SPM & 5.50 & $\begin{array}{c}1.70 \times 10^{7} \\
\left(0.56-4.11 \times 10^{7}\right)\end{array}$ & 309.1 & 0.51 & 0.22 & 68.00 \\
\hline BMM & 10.5 & $\begin{array}{c}2.27 \times 10^{8} \\
\left(0.64-11.60 \times 10^{8}\right)\end{array}$ & 216.2 & 0.67 & 0.02 & 4.32 \\
\hline
\end{tabular}

\footnotetext{
${ }^{a}$ See Table 1 for medium compositions.

${ }^{b}$ Mean $(95 \%$ confidence interval) spore concentration of inoculum $(50 \mu \mathrm{l})$ needed to be added to artificial diet to cause $50 \%$ mortality of $A$. gemmatalis third-instar larvae.

'Volume $(\mathrm{ml})$ of fermented medium needed to prepare 11 of suspension at $\mathrm{LC}_{50}$ for A. gemmatalis third-instar larvae. Volume $(\mathrm{ml})=\mathrm{LC}_{50} \times 10^{3} /$ yield.

${ }^{d}$ Logarithm (base 10) of dilution needed to obtain suspension at $\mathrm{LC}_{50}$ from fermented medium. Dilution factor $=\log _{10}\left(\right.$ yield $\left./ \mathbf{L C}_{50}\right)$.

${ }^{e}$ Considering cost of raw materials in São Paulo state, Brazil.

${ }^{f}$ Cost of 10001 of suspension at $\mathrm{LC}_{50}$. Relative cost $=$ medium $\operatorname{cost} / 10^{\text {(dilution factor). }}$
}

the $\mathrm{LC}_{50}$ value of the final product obtained with $\mathrm{BMM}$ was more than 75 times higher than the $\mathrm{LC}_{50}$ for NBY (Table 2), the relative cost was lower for BMM due to the low cost of the medium ingredients. Only $18.9 \mathrm{ml}$ of fermented NBY medium were necessary to produce 11 of suspension at $\mathrm{LC}_{50}$. However, the $216.2 \mathrm{ml}$ of $\mathrm{BMM}$ medium needed to produce similar suspension were produced at lower cost. The high potency of the product obtained in NBY $\left(\mathrm{LC}_{50}=2.99 \times 10^{6}\right.$ spores $\left./ \mathrm{ml}\right)$ was not sufficient to compensate for the lower yield and higher cost of ingredients in this medium.

The cost analysis suggests that BMM medium would be preferred for production of B. thuringiensis var. kurstaki, in relation to other media tested. NBY and WSM had intermediate relative cost approximately nine times higher than BMM. SPM medium should be avoided due to its low yield and potency which caused the relative cost for this medium to be greater than 15 times higher than the best medium. The results of the cost analysis also demonstrate the importance of considering not only the yields but also cost and potency of the preparations in determining the best medium for production. Spore counts or potencies should not be used alone in the selection of preferred culture medium.

\section{REFERENCES}

Alves, L.F.A., Alves, S.B. \& Batista Filho, A. (1993) Produção de Bacillus thuringiensis var. kurstaki utilizando levedura de cana, in $14^{\circ}$ Congresso Brasileiro de Entomologia-Resumos, Sociedade Entomológical do Brasil, Piracicaba, Brazil, p. 325.

Alves, L.F.A., Alves, S.B. \& CAPAlbo, D.M.F. (1997) Seleção de matéria prima para a elaboração de meio de cultura para produção de Bacillus thuringiensis var. kurstaki. Anais da Sociedade Entomológica do Brasil 26, 379-382.

AOAC (1975) Official Methods of Analysis of the Association of Official Analytical Chemists. Association of Official Analytical Chemists, Washington.

arcas, J., Yantorno, O., Arrarás, E. \& Ertola, R. (1984) A new medium for growth and $\delta$-endotoxin production by Bacillus thuringiensis var. kurstaki. Biotechnology Letters 6, 495-500.

Briggs, J.D. (1963) Commercial productions of insect pathogens, in Insect Pathology (Steinhaus, E.A., Ed.) Academic Press, New York, Vol. 2, pp. 519-548.

Capalbo, D.M.F., Moraes, I.O., Sobrinho, M.R. \& ConTi, H.H. (1991) Obtenção de bioinseticida à base de Bacillus thuringiensis em novos meios de cultura. Pesticidas-Revista Técnico Científica 1, 13-19.

Couch, T.L. \& Ross, D.A. (1980) Production and utilization of Bacillus thuringiensis. Biotechnology and Bioengineering 22, 1297-1304. 
Dulmage, H.T. (1970) Production of the spore- $\delta$-endotoxin complex variants of Bacillus thuringiensis in two fermentation media. Journal of Invertebrate Pathology 16, 385-389.

Faloci, M.M., Yantorno, O.M., Marino, H.A., Arcas, J.A. \& Ertola, R.J. (1993) Effect of the media composition on the growth parameters and biological properties of Bacillus thuringiensis var. kurstaki $\delta$-endotoxin. World Journal of Microbiology and Biotechnology 6, 32-38.

Fernandez, W.L., OCAmpo, T.A. \& Perez, D.C. (1975) Coconut water in three media reduces cell yield of Bacillus thuringiensis var. kurstaki Berliner. Philippine Agriculturist 58, 273-279.

Foda, M.S., Salama, H.S. \& FAdel, M. (1993) Local production of Bacillus thuringiensis in Egypt: advantages and constraints, in Proceedings 1st International Workshop on Bacillus thuringiensis and Its Application as It Relates to Developing Countries, NCR/Cairo, Cairo, pp. 149-165.

Goldberg, I., Sneh, B., BatTat, E. \& Klein, D. (1980) Optimization of a medium for a high yield production of spore-crystal preparation of Bacillus thuringiensis effective against the Egyptian cotton leaf worm Spodoptera littoralis Boisd. Biotechnology Letters 2, 419-426.

Greene, G.L., Leppla, N.C. \& Dickerson, W.D. (1976) Velvetbean caterpillar: a rearing procedure and artificial medium. Journal of Economic Entomology 69, 487-488.

Mummigatti, S.G. \& Raghunathan, A.N. (1990). Influence of media composition on the production of $\delta$-endotoxin by Bacillus thuringiensis var. thuringiensis. Journal of Invertebrate Pathology 55, 147-151.

Pantuwatana, S., Panbangred, W. \& Bhumiratana, A. (1993) Novel simple production and formulation techniques for Bacillus thuringiensis in Thailand, in Proceedings 1st International Workshop on Bacillus thuringiensis and Its Application as It Relates to Developing Countries, NCR/Cairo, Cairo, pp. $213-219$.

Pearson, D. \& WARD, O.P. (1988) Effect of culture conditions on growth and sporulation of Bacillus thuringiensis subsp. israelensis and development of media for production of the protein crystal endotoxin. Biotechnology Letters 10, 451-456.

Rodriguez, M., Razo, E., Villafana, E.L., UrquiJo, E. \& de la Torre, M. (1993) Development of a high productivity process for the production of bioinsecticides by Bacillus thuringiensis, in Proceedings 1st International Workshop on Bacillus thuringiensis and Its Application as It Relates to Developing Countries, NCR/Cairo, Cairo, pp. 137-147.

Sakharova, Z.V., Rabotnova, I.L. \& Khovrychev, M.P. (1988) Growth and spore-formation in Bacillus thuringiensis at high substrate concentrations. Mikrobiologiya 57, 992-995.

Salama, H.S., Foda, M.S., Dulmage, H.T. \& El-Sharaby, A. (1983a) Novel fermentation media for production of $\delta$-endotoxin from Bacillus thuringiensis. Journal of Invertebrate Pathology 41, 8-19.

Salama, H.S., Foda, M.S., El-Sharaby, A. \& Selim, M.H. (1983b) A novel approach for whey recycling in production of bacterial insecticides. Entomophaga 28, 151-160.

Salama, H.S., Foda, M.S., Selim, M.H. \& El-Sharaby, A. (1983c) Utilization of fodder yeast and agro-industrial by-products in production of spores and biologically active endotoxins from Bacillus thuringiensis. Zentralblatt fur Mikrobiologie 83, 553-563.

Scherrer, P., Lüthy, P. \& Trumpi, B. (1973) Production of $\delta$-endotoxin by Bacillus thuringiensis as a function of glucose concentrations. Applied Microbiology 25, 644-646.

Tosi, H. \& Favoretto, V. (1989) Apostila de Aula do Curso de Pós-Graduação em Produção Animal, Faculdade de Ciências Agrárias e Veterinárias de Jaboticabal/UNESP, UNESP, Jaboticabal.

Ventosilla, P., Snyder, M., Velez, J., Guerra, H. \& Novak, P. (1994) Community biological control of malaria using coconut-produced Bacillus thuringiensis var. israelensis (Bti) H-14 in Piura, Peru, in $4^{\circ}$ Simpósio de Controle Biológico-Resumos, EMBRAPA/CPACT, Pelotas, p. 124. 